\title{
PERANAN KERJASAMA BISNIS TERHADAP PENINGKATAN VOLUME PENJUALAN PADA TOKO MEDIA PRINT PEMATANGSIANTAR
}

\author{
Oleh: \\ Erbin Chandra \\ S1 Manajemen \\ Darwin Lie, Marisi Butarbutar, Efendi
}

Abstraksi

Toko Media Print Pematangsiantar adalah toko yang bergerak dalam bidang percetakan. Percetakan yang dilakukan adalah percetakan digital dan offset. Untuk membantu meningkatkan volume penjualannya, Toko Media Print melakukan kerjasama bisnis dengan beberapa perusahaan. Namun kenyataannya kerjasama bisnis yang dilakukan masih belum mampu memberikan volume penjualan yang sesuai dengan harapan. Maka berdasarkan uraian di atas yang menjadi rumusan masalah, yaitu "Bagaimana peranan kerjasama bisnis terhadap peningkatan volume penjualan pada Toko Media Print Pematangsiantar?".

Adapun metodologi penelitian yang digunakan dengan penelitian kepustakaan dan penelitian lapangan, jenis datanya adalah data kualitatif dan kuantitatif, sumber data dalam penelitian ini adalah data primer dan sekunder. Data diperoleh dengan cara melakukan observasi, wawancara dan dokumentasi. Berdasarkan analisis dan evaluasi yang dilakukan, disimpulkan bahwa kerjasama bisnis yang dilakukan oleh Toko Media Print Pematangsiantar berperan dalam meningkatkan volume penjualan. Tetapi volume penjualan dari hasil kerjasama tersebut masih belum optimal karena jumlah pendapatan yang diperoleh masih relatif rendah. Hal ini disebabkan ada beberapa hal yang masih belum dilakukan, dimana Toko Media Print hanya melaksanakan kerjasama horizontal tetapi belum melaksanakan kerjasama vertikal dan konglomerat yang diharapkan akan memberikan keuntungan yang lebih besar.

Kata kunci: Kerjasama Bisnis dan Volume Penjualan

\section{Abstraction}

Print Media Store Pematangsiantar is a store that specializes in printing. Printing is done is digital and offset printing. To help increase sales volume, Print Media Store business cooperation with several companies. But in reality do business cooperation is still not able to provide the volume of sales in line with expectations. So based on the above description that the formulation of the problem, namely "How the role of business cooperation to increased sales volume in the Print Media Store Pematangsiantar?".

The research methodology used in the research literature and field research, the type of data is qualitative and quantitative data, the source of the data in this study are primary and secondary data. Data obtained by observation, interviews and documentation. Based on the analysis and evaluation, concluded that the cooperation of business done by the Print Media Store Pematangsiantar role in increasing sales volume. But the sales volume of the results of such cooperation is still not optimal because of the amount of earned income is still relatively low. This is because there are some things that have not been done, where the Print Media Store only implement horizontal cooperation but not implement vertical and conglomerate cooperation which is expected to provide greater profits.

Keywords : Business Cooperation and Volume Sales

\section{A. PENDAhuluan}

\section{Latar Belakang Masalah}

Toko Media Print Pematangsiantar adalah toko yang bergerak dalam usaha percetakan. Jenis percetakan yang dilakukan adalah percetakan offset dan digital. Contoh-contoh hasil cetakan yang dilakukan adalah undangan, brosur, kartu nama, spanduk, kartu ID dan lain-lain.

Volume penjualan adalah total keuntungan bersih yang diterima suatu perusahaan sebagai hasil dari menjual produk atau jasa yang dihasilkannya kepada konsumen. Volume penjualan merupakan hal yang sangat penting untuk semua jenis usaha karena dari volume penjualan tersebut menentukan keuntungan yang diterima suatu perusahaan. Untuk itu semua perusahaan terus berusaha untuk meningkatkan volume penjualannya. Begitu juga dengan Toko Media Print yang mempunyai harapan untuk mampu mencapai keuntungan yang sebesarbesarnya dengan cara terus meningkatkan volume penjualannya.

Salah satu cara yang dilakukan oleh Toko Media Print untuk meningkatkan volume penjualannya adalah dengan cara menjalin kerjasama bisnis. Kerjasama bisnis ini dilakukan dengan harapan mampu membantu meningkatkan volume penjualan. Adapun data penjualan Toko Media Print Pematangsiantar dari tahun 2010 s/d 2013 dapat dilihat pada tabel di bawah ini. 
Tabel 1

Data Penjualan Toko Media Print Pematangsiantar Tahun 2010 s/d 2013

\begin{tabular}{|c|c|c|c|}
\hline Tabus & 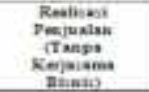 & 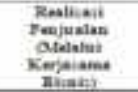 & Tutal \\
\hline 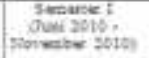 & 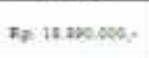 & Ro, 3sesese & Fi, $22+16 \sec$. \\
\hline 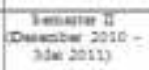 & $x=21+28000$ - & $\Rightarrow=1012$ tobe. & $x=12=26.0000$ \\
\hline 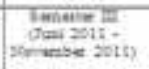 & 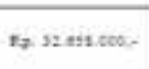 & $B=4.060 .000$, & $27,3: 454.000$ \\
\hline 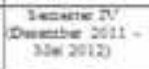 & 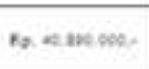 & $R_{0}=2 a n c 06$ & 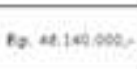 \\
\hline 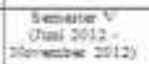 & 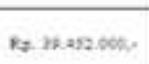 & 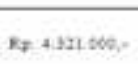 & $k=1375.006$. \\
\hline 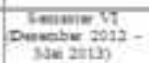 & 1*) Netecote. & $\Rightarrow 4+2 a 000$, & $18+22=55,000$ \\
\hline
\end{tabular}

Berdasarkan data penjualan di atas dapat terlihat bahwa hasil realisasi penjualan melalui kerjasama bisnis memberikan kontribusi yang relatif masih sedikit pada total penjualan. Untuk itu Toko Media Print ingin meningkatkan kerjasama bisnis dengan perusahaan lain (misalnya dengan sekolah, bank, restaurant, dan lain-lain) sehingga mampu meningkatkan volume penjualan yang lebih besar.

\section{Rumusan Masalah}

Dengan dasar pemikiran diatas, maka diidentifikasikan rumusan masalah penelitian sebagai berikut: "Bagaimana peranan kerjasama bisnis terhadap peningkatan volume penjualan pada Toko Media Print Pematangsiantar?"

\section{Tujuan Penelitian}

Adapun tujuan penelitian ini adalah untuk mengetahui peranan kerjasama bisnis terhadap peningkatan volume penjualan pada Toko Media Print Pematangsiantar.

\section{Metode Penelitian}

Desain penelitian merupakan suatu cara yang sistematis dan objektif dengan maksud untuk memperoleh data atau mengumpulkan keterangan untuk diteliti. Adapun desain penelitian yang digunakan dalam penelitian ini adalah Penelitian Kepustakaan (Library Research) dan Penelitian Lapangan (Field Research). Sumber data yang digunakan dalam penelitian ini adalah data primer dan data sekunder.

Teknik pengumpulan data yang dilakukan penulis dalam penelitian ini adalah berupa wawancara, dokumentasi, dan observasi. Teknik analisa data yang digunakan dalam penelitian ini antara lain Teknik Analisa Deskriptif Kualitatif dan Teknik Analisa Komparatif.

\section{B. LANDASAN TEORI}

David (2006:5) mengemukakan bahwa manajemen strategis (strategic management) dapat didefinisikan sebagai seni dan ilmu untuk memformulasi, mengimplementasi dan mengevaluasi keputusan lintas fungsi yang memungkinkan organisasi dapat mencapai tujuannya.
Menurut Tangkilisan (2005:86), kerjasama adalah semua kekuatan yang timbul diluar batasbatas organisasi yang dapat mempengaruhi keputusan serta tindakan di dalam organisasi. Karenanya perlu diadakan kerjasama dengan kekuatan yang diperkirakan mungkin akan timbul. Kerjasama tersebut dapat didasarkan atas hak, kewajiban dan tanggung jawab masing-masing orang untuk mencapai tujuan.

Menurut Kasmir dan Jakfar (2010:5) bisnis adalah kegiatan atau usaha yang dilakukan untuk memperoleh keuntungan sesuai dengan tujuan dan target yang diinginkan dalam berbagai bidang, baik jumlah maupun waktunya. Jafar dalam Seplita (2012:1) menyebut kerjasama bisnis dengan istilah "kemitraan", yang artinya adalah suatu strategi bisnis yang dilakukan oleh dua pihak atau lebih dalam jangka waktu tertentu untuk meraih keuntungan bersama dengan prinsip saling membutuhkan dan saling membesarkan.

Menurut Tim PPM (2012:204), di dalam melakukan kerjasama bisnis di dalam suatu organisasi, memiliki empat tujuan yaitu :

1. Kemitraan untuk tujuan optimasi operasi dengan fokus pada kompetensi dan kegiatan inti. Kegiatan dan kompetensi non inti diserahkan kepada mitra. Bentuk kemitraan semacam ini dikenal dengan istilah alih daya atau outsourcing.

2. Kemitraan dengan tujuan mendapatkan sumber daya yang tidak dimiliki. Salah satu bentuk sumber daya yang paling lumrah untuk didapatkan dari mitra kerja antara lain: basis data konsumen, brand yang kuat, atau teknologi dan paten teknologi.

3. Kemitraan dengan tujuan mendapatkan pengetahuan secara organisasi. Organisasi membutuhkan pengetahuan untuk menjalankan operasinya, dan pengetahuan tersebut dimiliki oleh mitra. Salah satu bentuk kemitraan semacam ini dikenal dengan joint operation.

4. Kemitraan untuk tujuan akuisisi pasar, baik untuk mengembangkan ataupun membuka pasar baru. Bentuk yang paling sering dijumpai ialah joint venture untuk mengembangkan pasar internasional. Khusus kemitraan dalam pengembangan pasar, organisasi yang bermitra bisa bekerja sama namun tetap bersaing pada saat penjualan.

Purnomo, Cita dan Iswi (2013:239) menyatakan bahwa bermitra adalah cara yang tepat untuk sama-sama menumbuhkan ekonomi bangsa sekaligus menyerap tenaga kerja.

Menurut Boone dan David (2007:270) jenis kemitraan usaha atau kerjasama bisnis yang yang dilakukan pada saat sekarang terbagi menjadi:

1. Merger dan Akuisisi (M\&A)

Istilah merger dan akuisisi sering kali digunakan bergantian, tetapi sesungguhnya kedua istilah tersebut memiliki arti yang berbeda. Dalam suatu merger, dua atau lebih perusahaan bergabung untuk membentuk suatu perusahaan. Dalam suatu akuisisi, satu perusahaan membeli 
properti dan mengambil alih dari perusahaan lain.

2. Usaha Patungan : Persekutuan Khusus

Usaha patungan adalah persekutuan antara perusahaan-perusahaan yang dibentuk untuk tujuan tertentu. Kadang kala suatu perusahaan membentuk usaha patungan dengan perusahaan lokal atau pemerintah, dalam rangka berbagi biaya operasional, risiko, manajemen dan laba dengan sekutu lokalnya.

Jafar dalam Gunardi (2011:6) menjelaskan rangkaian urutan proses kerjasama bisnis sebagai berikut:

1. Memulai membangun hubungan dengan calon mitra.

Hal ini dimaksudkan agar kita dapat mengenal pihak atau orang yang akan dijadikan calon mitra dengan baik dan tepat.

2. Mengerti kondisi bisnis pihak yang bermitra atau bekerja sama.

Apabila calon mitra kita adalah orang yang telah punya pengalaman berbisnis, maka kita harus mengetahui bagaimana kemampuan manajemennya, teknologinya, sumber daya manusia dan sumber daya fiansialnya. Sedangkan, apabila calon mitra kita adalah orang yang tidak atau belum memiliki pengalaman usaha, maka kita pun patut untuk mengetahui keahlian atau keterampilan serta modal apa yang dimilikinya, sehingga kita layak mempertimbangkannya sebagai calon mitra usaha kita.

3. Mengembangkan strategi dan mengenal detail bisnis.

Bila telah ditetapkan calon mitra, maka langkah selanjutnya adalah bagaimana mengembangkan strategi usaha. Hal ini dapat dilakukan dengan cara membagi tugas dengan pihak yang bermitra sesuai dengan informasi dan kemampuan yang dimiliki masing-masing. Dengan strategi dan mengenal detail bisnis yang tepat, maka kita akan dapat mengembangkan usaha dengan tepat pula, sehingga akan mendatangkan keuntungan kedua pihak (win-win solution)

4. Mengembangkan program

Pengembangan program merupakan langkah yang dilakukan setelah mengembangkan strategi bisnis dan merupakan rencana taktis yang akan dilaksanakan. Hal ini kemudian perlu diinformasikan kepada semua pihak yang akan terlibat dalam kerjasama tersebut, sehingga semua pihak siap untuk melaksanakannya.

5. Memulai pelaksanaan

Setelah semua siap, barulah usaha dalam bentuk kerjasama atau kemitraan tersebut dilaksanakan. Dalam awal pelaksanaan perlu dicek kesiapankesiapan serta memprediksi kemungkinankemungkinan yang akan terjadi.

6. Memonitoring dan mengevaluasi perkembangan.

Selama proses pelaksanaan perlu ada monitoring, sehingga dapat dievaluasi kekurangan-kekurangan atau hambatan- hambatan yang dihadapi. Dengan melakukan monitoring dan evaluasi, maka selanjutnya dapat dilakukan penyesuaian atau perbaikan-perbaikan sebagaimana yang diperlukan.

Purnomo, Cita dan Iswi (2013:248) mengemukakan bahwa perjanjian kemitraan dituangkan dalam perjanjian tertulis yang sekurangkurangnya mengatur kegiatan usaha, hak dan kewajiban masing-masing pihak, bentuk pengembangan, jangka waktu dan penyelesaian perselisihan. Purnomo, Cita dan Iswi (2013:251) juga menjelaskan bahwa usaha besar, usaha menengah dan usaha mikro/usaha kecil yang melaksanakan kemitraan mempunyai hak untuk:

1. Meningkatkan efisiensi usaha dalam kemitraan

2. Mendapat kemudahan untuk melakukan kemitraan

3. Membuat perjanjian kemitraan

4. Membatalkan perjanjian bila salah satu pihak mengingkari

Winardi (2000:500) menjelaskan bahwa volume penjualan adalah jumlah benda-benda yang dihasilkan dari hubungan antara biaya yang dikeluarkan perusahaan dengan target penjualan untuk mencapai tujuan perusahaan, yang terdiri atas produsen, konsumen dan keadaan lain di luar produsen dan konsumen. Menurut Gunardi (2011:1), salah satu kunci sukses usaha adalah sukses dalam kerjasama usaha. Menurut Purnomo, Cita dan Iswi (2013:199), pada kondisi di mana terdapat dua atau lebih perusahaan bergabung, maka pangsa pasar kedua perusahaan yang bergabung tersebut akan bersatu dan membentuk gabungan pangsa pasar yang lebih besar.

\section{PEMBAHASAN}

\section{Analisa}

\section{a. Deskripsi Kualitatif}

Toko Media Print Pematangsiantar bergerak dalam usaha percetakan yaitu percetakan offset dan digital. Di dalam menjalankan usahanya, Toko Media Print melakukan kerjasama bisnis dengan harapan mampu meningkatkan volume penjualan. Kerjasama Bisnis yang dilakukan adalah kerjasama horizontal yaitu Toko Media Print hanya melakukan kerjasama dengan perusahaan yang sejenis atau perusahaan yang juga bergerak dalam bidang percetakan. Dengan kerjasama bisnis, Toko Media Print menerima bantuan pekerjaan dari para mitranya ketika menerima orderan yang terlalu banyak atau yang tidak mampu dilakukan demikian juga sebaliknya. Mitra-mitra bisnis dari Toko Media Print adalah U. D. Sinar Abadi Pematangsiantar, U. D. Sentral Jaya Pematangsiantar, C. V. Evolution Grapix Pematangsiantar dan Vista Advertising Pematangsiantar.

Kesepakatan-kesepakatan kerjasama bisnis antara Toko Media Print dan para mitranya telah dibuat dalam suatu bentuk perjanjian sehingga apabila ada kesepakatan yang dilanggar salah satu pihak maka kerjasama bisnis tersebut akan diakhiri. Melalui pembahasan analisis tersebut penulis akan menguraikan jumlah hasil volume penjualan Toko 
Media Print Pematangsiantar tanpa kerjasama bisnis dengan hasil volume penjualan dengan kerjasama bisnis dan total dari kedua hasil tersebut sehingga dapat diketahui bagaima peranan kerjasama bisnis terhadap peningkatkan volume penjualan pada Toko Media Print Pematangsiantar.

\section{b. Deskripsi Komparatif}

1) Volume Penjualan Toko Media Print Pematangsiantar Tanpa Kerjasama Bisnis

Melalui hasil analisis penulis berpedoman data hasil penjualan dari Toko Media Print Pematangsiantar, penulis dapat menguraikan hasil realisasi penjualan tanpa kerjasama bisnis seperti tabel di bawah ini.

Tabel 2

Realisasi Penjualan Tanpa Kerjasama Bisnis Tahun 2010 s/d 2013

\begin{tabular}{|c|c|}
\hline Tabuu & Realisasi Penjualan \\
\hline $\begin{array}{c}\text { Semester ! } \\
\text { (Juni 2010 - November 2010) }\end{array}$ & Rp. 18.890 .000 \\
\hline $\begin{array}{c}\text { Semester II } \\
\text { (Desembet 2010- Mei 2011) }\end{array}$ & Rp. 20.452 .000 , \\
\hline $\begin{array}{c}\text { Semester III } \\
\text { (Juni } 2011 \text { - November 2011) }\end{array}$ & Rp. 32.658 .000 , \\
\hline $\begin{array}{c}\text { Semester IV } \\
\text { (Desember 2011 - Mei 2012) }\end{array}$ & Rp. 40.890 .000 \\
\hline $\begin{array}{c}\text { Semester V } \\
\text { (Juni 2012 - Novernber 2012) }\end{array}$ & Rp. $39.452 .000=$ \\
\hline $\begin{array}{c}\text { Semester VI } \\
\text { (Desember 2012 - Me1 2013) }\end{array}$ & Rp. 37.658 .000 , \\
\hline
\end{tabular}

Berdasarkan data dari Toko Media Print, pada semester IV jumlah orderan adalah terbanyak dibandingkan dengan semester lainnya. Tetapi pada semester $\mathrm{V}$, jumlah volume penjualan mengalami penurunan dengan total volume penjualan sebesar Rp. 39.452.000,- atau persentase indeks sebesar 208,8\%. Pada semester VI, terjadi penurunan lagi dibandingkan dengan semester $\mathrm{V}$, yaitu dengan total volume penjualan sebesar Rp. 37.658.000,- dan persentase indeks sebesar 199,3\%. Penurunan tersebut terjadi karena berkurangnya jumlah orderan pada bulan Juni 2012 dan Februari 2013 dikarenakan Toko Media Print melakukan libur yang cukup lama pada bulan Juli 2012 dan bulan Februari 2013 sehingga mengalami penurunan penjualan.

a) Volume Penjualan Toko Media Print Pematangsiantar Melalui Kerjasama Bisnis

Dari hasil analisa penulis, realisasi penjualan

Toko Media Print Pematangsiantar yang diterima melalui kerjasama bisnis dapat diuraikan pada tabel di bawah ini.

Tabel 3

Realisasi Penjualan Melalui Kerjasama Bisnis Tahun 2010 s/d 2013

\begin{tabular}{|c|c|}
\hline Tahun & Realisasi Penjualan \\
\hline $\begin{array}{c}\text { Semester I } \\
\text { (Juni 2010-November 2010) }\end{array}$ & Rp. 3.526.000,- \\
\hline $\begin{array}{c}\text { Semester II } \\
\text { (Desember 2010 - Mei 2011) }\end{array}$ & Rp. 5.012.000,- \\
\hline $\begin{array}{c}\text { Semester III } \\
\text { (Jum 2011 - November 2011) }\end{array}$ & Rp. 4.980 .000 - \\
\hline $\begin{array}{c}\text { Semester IV } \\
\text { (Desember 2011 - Mei 2012) }\end{array}$ & Rp. 5.250.000,- \\
\hline $\begin{array}{c}\text { Semester V } \\
\text { (Juni 2012 - November 2012) }\end{array}$ & Rp. 4.321.000,- \\
\hline $\begin{array}{c}\text { Semester VI } \\
\text { (Desember 2012 - Mei 2013) }\end{array}$ & Rp. 4.745.000,- \\
\hline
\end{tabular}

Data di atas menunjukkan volume penjualan tertinggi adalah pada semester IV dengan total volume penjualan sebesar Rp. 5.250.000,- dan persentase indeks sebesar $148,9 \%$. Pada semester V terjadi penurunan yang cukup tinggi yaitu volume penjualan hanya mencapai Rp. 4.321.000,- dengan persentase indeks sebesar $122,5 \%$. Tetapi pada semester VI terjadi peningkatan dengan volume penjualan sebesar $\mathrm{Rp}$ 4.745.000,- dan persentase indeks sebesar $134,6 \%$. Penurunan tersebut terjadi karena mulai semester III, jumlah mitra bisnis dari Toko Media Print Pematangsiantar berkurang drastis tetapi pada semester III dan IV jumlah volume penjualan melalui kerjasama bisnis tersebut masih belum mengalami penurunan yang besar dikarenakan ada pekerjaan dengan hasil keuntungan yang besar dari salah satu mitra bisnis. Tetapi pada semester $\mathrm{V}$ dan VI jumlah mitra bisnis kembali mengalami penurunan yang menyebabkan semakin menurunnya jumlah volume penjualan.

b) Total Volume Penjualan Toko Media Print Pematangsiantar Tanpa Kerjasama Bisnis dan Melalui Kerjasama Bisnis

Setelah mendapatkan hasil volume penjualan tanpa kerjasama bisnis dan dengan kerjasama bisnis pada Toko Media Print Pematangsiantar, maka selanjutnya penulis akan menjumlahkan keseluruhan volume penjualan tersebut yang dapat dilihat pada tabel di bawah ini.

Tabel 4

Total Realisasi Penjualan Tanpa Kerjasama Bisnis dan Melalui Kerjasama Bisnis Tahun 2010 s/d 2013

\begin{tabular}{|c|c|}
\hline \\
\hline frahun & Realisasi Peujualan \\
\hline $\begin{array}{c}\text { Semester } 1 \\
\text { Jum } 2010 \text { - November } 2010 \text { ) }\end{array}$ & Rp. 3.526 .000 \\
\hline $\begin{array}{c}\text { Semester II } \\
\text { (Desember 2010- Mei 2011) }\end{array}$ & Rp. $5.012,000,-$ \\
\hline $\begin{array}{c}\text { Semester III } \\
\text { (Jumi } 2011 \text { - Novernber 2011) }\end{array}$ & Rp. $4980.000,-$ \\
\hline $\begin{array}{c}\text { Semester IV } \\
\text { (Desember 2011 - Mei 2012) }\end{array}$ & Rp. $5,250.000,-$ \\
\hline $\begin{array}{c}\text { Semester V } \\
\text { (Juni 2012-November 2012) }\end{array}$ & Rp. 4.321.000,- \\
\hline $\begin{array}{c}\text { Semester Vi } \\
\text { (Desember 2012 - Mei 2013) }\end{array}$ & Rp, 4,745.000,- \\
\hline
\end{tabular}

Data di atas menunjukkan jumlah volume penjualan dari semester I terus mengalami peningkatan dan pencapaian tertinggi adalah pada semester IV sebesar Rp 46.140.000,- dengan 
persentase indeks sebesar $205,8 \%$. Penurunan terjadi pada semester $\mathrm{V}$ dengan volume penjualan sebesar Rp. 43.773.000,- dan persentase indeks 195,2\%. Pada semester VI terjadi lagi penurunan dengan volume penjualan sebesar Rp 42.403.000,- dan persentase indeks sebesar 189,2\%. Penurunan tersebut terjadi dikarenakan sejak semester III, jumlah mitra bisnis dari Toko Media Print Pematangsiantar mengalami penurunan. Pada semester V dan VI jumlah mitra bisnis kembali berkurang yang menyebabkan total volume penjualan yang berkurang. Salah satu cara yang dapat dilakukan Toko Media Print untuk mampu semakin meningkatkan volume penjualannya adalah mencari lebih banyak mitra bisnis untuk bekerja sama.

c) Rasio / Persentase Volume Penjualan Berdasarkan Kerjasama Bisnis Dengan Total Penjualan

Tabel 5

Rasio / Persentase Volume Penjualan

Berdasarkan Kerjasama Bisnis Dengan Total Penjualan Tahun 2010 s/d 2013

\begin{tabular}{|c|c|c|c|}
\hline Thas & 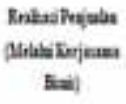 & 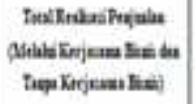 & 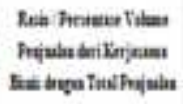 \\
\hline 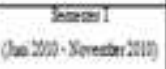 & 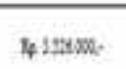 & 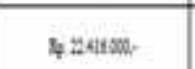 & as \\
\hline 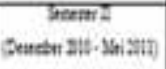 & 4:5t:200. & 4 & $3 \pi$ \\
\hline 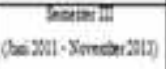 & 445000 & \& 41 tature & us \\
\hline 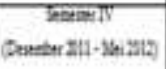 & $4: 22010$ & 4 atatow & 145 \\
\hline 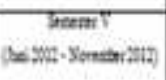 & 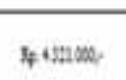 & \& etrom & k \\
\hline 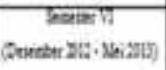 & 4.6400 & $\$ \mathrm{sen}=0$ & ns \\
\hline
\end{tabular}

Sumber: Toko Media Print Pematangsiantar

Berdasarkan data yang tertera di atas, dapat dilihat rasio / persentase volume penjualan tanpa kerjasama bisnis dengan total penjualan Toko Media Print Pematangsiantar tahun 2010 s/d 2013 dengan kategori per semester. Data di atas menunjukkan pada semester I peran dari kerjasama bisnis adalah sebesar $15,7 \%$. Pada semester II, peran dari kerjasama bisnis memberikan hasil yang paling tinggi yaitu sebesar 19,7\% karena pada semester II, Toko Media Print melakukan kerjasama bisnis dengan jumlah mitra bisnis yang paling banyak. Pada semester III, jumlah mitra bisnis dari Toko Media Print berkurang karena faktor-faktor tertentu yang menyebabkan peran dari kerjasama bisnis menurun menjadi13,2\%. Namun penurunan tersebut tidak sepenuhnya dikarenakan berkurangnya jumlah mitra bisnis.
Analisis sebelumnya menunjukkan bahwa pada semester III jumlah volume penjualan melalui kerjasama bisnis tidak mengalami penurunan yang terlalu banyak dibandingkan dengan semester II. Peran kerjama bisnis pada semester III menurun karena volume penjualan tanpa kerjasama bisnis pada semester III meningkat drastis yang menyebabkan peran kerjasama bisnis terlihat menurun pada semester III. Penurunan tersebut terjadi lagi pada semester IV dengan hasil sebesar $11,4 \%$ dan semester V sebesar 9,9\%. Sama halnya dengan semester III, penurunan peran dari kerjasama bisnis tersebut bukan dikarenakan berkurangnya volume dari kerjasama bisnis. Seperti analisis sebelumnya, jumlah volume penjualan tertinggi melalui kerjasama bisnis adalah pada semester IV. Peran dari kerjasama bisnis pada semester IV terlihat menurun dikarenakan volume penjualan Toko Media Print tanpa kerjasama bisnis pada semester IV mencapai jumlah tertinggi dari semester-semester lainnya. Pada semester VI peran kerjasama bisnis mengalami sedikit peningkatan yaitu dengan hasil $11,2 \%$

Dari hasil analisis di atas, dapat disimpulkan bahwa Hipotesis yang penulis buat yaitu pelaksanaan kerjasama bisnis yang dilakukan oleh Toko Media Print Pematangsiantar dapat diterima.

\section{Evaluasi}

\section{a. Kerjasama Bisnis}

Toko Media Print Pematangsiantar mempunyai tujuan yaitu ingin mencapai keuntungan yang sebesar-besarnya dengan cara meningkatkan volume penjualan. Salah satu cara yang dilakukan Toko Media Print untuk merealisasikan tujuannya adalah menjalin kerjasama bisnis dengan perusahaan-perusahaan lain. Adapun jenis kerjasama bisnis yang dilakukan Toko Media Print adalah kerjasama horizontal. Evaluasi yang dapat diberikan penulis adalah sebagai berikut:

1) Proses-proses dalam melakukan kemitraan oleh Toko Media Print sebenarnya telah menerapkan hal-hal penting yang harus dilakukan namun mengenai proses pengembangan program masih tidak dilakukan dengan baik karena dianggap tidak begitu penting dan kerjasama hanya sebatas pembagian pekerjaan saja tanpa membahas mengenai program-program yang harus dijalankan. Jika adanya program-program yang jelas ditetapkan, tentu proses pekerjaan dapat dilakukan dengan lebih baik dan teratur.

2) Mengenai proses monitoring masih jarang dilakukan antara Toko Media Print dan para mitra bisnis sehingga banyak kekurangankekurangan dan hambatan-hambatan yang seharusnya diperbaiki menjadi tertunda. Proses monitoring dan pengevaluasian seharusnya harus rutin dikerjakan agar pekerjaan dapat dilakukan dengan lebih optimal.

3) Dalam masalah resiko, tidak ada kesepakatan antara para mitra untuk saling menanggung kerugian bersama walaupun kerugian itu didapatkan oleh salah satu pihak ketika 
melakukan pekerjaan mitranya. Dengan demikian tidak adanya pembagian yang proporsional jika yang dibagi hanyalah keuntungan belaka dan mengabaikan kerugian. Kerjasama akan lebih erat dan lebih bertahan lama jika adanya kesepakatan dalam penanggungan bersama masalah kerugian juga.

\section{b. Volume Penjualan}

Walaupun Toko Media Print Pematangsiantar telah melaksanakan proses-proses kerjasama bisnis dengan harapan mampu membantu meningkatkan volume penjualan, namun pencapaian tersebut masih belum mampu memenuhi harapan Toko Media Print. Dari hasil analisa di atas, dapat dilihat bahwa kerjasama bisnis yang dilaksanakan oleh toko Media Print memang memberikan peningkatan volume penjualan namun jumlah pendapatan yang diterima dari hasil kerjasama masih relatif rendah. Maka berdasarkan hasil penelitian, penulis dapat memberikan beberapa evaluasi mengenai cara meningkatkan volume penjualan melalui kerjasama bisnis pada Toko Media Print sebagai berikut:

1) Peranan kerjasama bisnis terhadap peningkatan volume penjualan dari Toko Media Print masih relatif rendah. Hal tersebut tampak pada hasil analisa di atas dimana peranan tertinggi dari hasil kerjasama bisnis hanya tercapai pada semester II dengan persentase $19,7 \%$ dan jumlah tersebut masih tergolong rendah. Tetapi pada semester III s/d semester V bahkan terjadi penurunan drastis diakibatkan mitra bisnis dari Toko Media Print yang semakin berkurang.

2) Cara untuk meningkatkan peranan kerjasama bisnis terhadap peningkatan volume penjualan pada Toko Media Print adalah dengan menambah lebih banyak mitra bisnis. Masalah yang dihadapi oleh Toko Media Print adalah berkurangnya mitra bisnis. Untuk itu Toko Media Print harus mencari kembali mitra bisnis yang lebih banyak untuk dapat kembali membantu meningkatkan volume penjualan melalui kerjasama bisnis.

3) Jenis kerjasama yang dilakukan oleh Toko Media Print hanya jenis kerjasama horizontal yaitu mitra bisnisnya cenderung melakukan jenis usaha yang sama tetapi Toko Media Print tidak melakukan jenis kerjasama vertikal kepada pemasok kertas, tinta cetakan dan kebutuhan percetakan lainnya sehingga biasanya Toko Media Print tidak membeli bahan kepada pemasok yang tetap dan harga yang didapat juga berbeda-beda karena pemasok yang berbeda. Dan sering juga Toko Media Print mendapatkan kesulitan mendapatkan bahan ketika para pemasoknya kehabisan bahan penjualan. Selain kerjasama vertikal, Toko Media Print dapat juga menerapkan kerjasama konglomerat misalnya dengan bank, sekolah, hotel dan perusahaanperusahaan lain untuk membantu menambah pelanggan dan memberikan profit yang lebih besar.

\section{KESIMPULAN DAN SARAN}

1. Kesimpulan

a. Pelaksanaan kerjasama bisnis yang dilakukan oleh Toko Media Print Pematangsiantar telah melalui survey dan penilaian terhadap calon mitra sehingga mitra-mitra bisnis yang telah bekerja sama dengan Toko Media Print adalah yang telah dianggap pantas dan cocok untuk bermitra.

b. Pencapaian volume penjualan dari hasil kerjasama bisnis yang dilakukan Toko Media Print Pematangsiantar masih relatif rendah. Dimana hasil tertinggi hanya tercapai pada semester II yaitu sebesar 19,7\% dan hasil ini juga masih relatif rendah. Pada semester III s/d semester $\mathrm{V}$ peran dari kerjasama bisnis mengalami penurunan drastis karena berkurangnya mitra bisnis. Pada semester VI, peran kerjasama bisnis terjadi peningkatan sedikit dengan persentase sebesar $11,2 \%$ namun dengan hasil yang masih relatif rendah jika dibandingkan dengan semester II.

c. Berdasarkan hasil analisa penulis, kerjasama bisnis mempunyai peranan dalam meningkatkan volume penjualan pada Toko Media Print Pematangsiantar. Dengan demikian Hipotesis dapat diterima.

d. Toko Media Print Pematangsiantar menerapkan prinsip win-win solution dengan membuat perjanjian dan kesepakatan yang tidak merugikan kedua belah pihak.

e. Didalam proses memulai kerjasama bisnis, Toko Media Print mengabaikan sistem pengembangan program dan setelah proses kerjasama berlanjut, kegiatan monitoring dan evaluasi sangat jarang dilakukan.

f. Diantara pihak Toko Media Print dan para mitra bisnisnya, tidak ada kesepakatan penanggungan kerugian secara bersama.

\section{Saran}

a. Proses pengembangan program harus dilakukan dengan baik agar proses pekerjaan dapat dilakukan dengan lebih teratur.

b. Kegiatan monitoring dan evaluasi harus lebih rutin dilakukan untuk mengetahui kekurangan masing-masing dan diperbaiki.

c. Pembagian yang rata bukan hanya pada profit saja. Diantara kedua pihak juga harus melakukan kesepakatan untuk saling menanggung kerugian yang berhubungan dengan kedua pihak sehingga proses kerjasama bisnis dapat berjalan lebih erat dan bertahan lama.

d. Untuk mampu meningkatkan peranan kerjasama bisnis terhadap peningkatan volume penjualan, Toko Media Print harus mampu mencari mitra bisnis yang lebih banyak.

e. Selain melaksanakan kerjasama horizontal, Toko Media Print seharusnya juga melakukan kerjasama vertikal terhadap pemasok kertas, tinta dan bahan percetakan lainnya untuk menghindari masalah kehabisan bahan dan 
menjamin lancarnya proses produktivitas. Toko Media Print juga hendaknya melakukan kerjasama konglomerat dengan bank, sekolah, hotel dan perusahaan lain untuk menambah jumlah pelanggan dan tentunya dapat menambah lebih banyak keuntungan.

f. Sehubungan dengan keterbatasan-keterbatasan yang ada pada penulis, penelitian ini masih terdapat kelemahan dan belum dapat mengungkap seluruh variabel yang dapat mempengaruhi volume penjualan pada Toko Media Print Pematangsiantar. Sebagai bahan masukan untuk penelitian selanjutnya, perlu memperbanyak variabel penelitian, seperti promosi, pelayanan prima, diferensiasi produk dan sebagainya.

\section{E. DAFTAR PUSTAKA}

David, Fred R. 2006. Manajemen Strategis. Jakarta: Penerbit Salemba Empat.

Gunardi, Yudhi.

2011.

http://www.google.com/url?sa=t\&rct=j\&q=gu nardi+kerjasama + bisnis\&source $=$ web $\& c d=2$ $\&$ cad $=$ rja \&ved $=0 \mathrm{CDQQFj} A B \&$ url $=\mathrm{http} \% 3 \mathrm{~A}$ $\% 2 \mathrm{~F} \% 2 \mathrm{Fkk} . \mathrm{mercubuana}$ ac.id\%2Ffiles\%2F9 9012-11-

269853546590.doc\&ei=L4CIUZCyEsrRrQfz p4G4CQ\&usg=AFQjCNHrOlw_m1lrCOkMHj
Q4jeV6stM77g\&bvm=bv.45960087,d.bmk, 2013.

Kasmir \& Jakfar. 2010. Studi Kelayakan Bisnis. Jakarta: Penerbit Kencana.

Purnomo, Serfianto D. \& Cita Yustisia Serfiyani \& Iswi Hariyani. 2013. Sukses Bisnis Ritel Modern. Jakarta: Penerbit PT Elex Media Komputindo.

Seplita, Mira. 2012. http://miraseplita.blogspot.com/2012/01/kerjasama.html, 2013.

Tangkilisan, Hessel Nogi S. 2005. Manajemen Publik. Jakarta: Penerbit Grasindo.

Tim PPM. 2012. Business Model Canvas. Jakarta: Penerbit PPM.

Winardi. 2000. Asas-Asas Manajemen. Bandung: Penerbit Mandar Maju. 